\title{
Complications in implant dentistry
}

\author{
Ayesha Hanif ${ }^{1}$, Saima Qureshi ${ }^{1}$, Zeeshan Sheikh ${ }^{2}$, Haroon Rashid ${ }^{3}$
}

Correspondence: Dr. Haroon Rashid Baloch

Email: drh.rashid@hotmail.com

\begin{abstract}
'Division of Clinical Periodontology, Faculty of Dentistry, Ziauddin University, Karachi, Pakistan, ${ }^{2}$ Matrix Dynamics Group, Faculty of Dentistry, University of Toronto, Toronto, Ontario, Canada, ${ }^{3}$ Division of Prosthodontics, Faculty of Dentistry, Ziauddin University, Karachi, Pakistan
\end{abstract}

\section{ABSTRACT}

After tooth loss, an individual may seek tooth replacement so that his/her function and esthetics could be restored. Clinical prosthodontics, during the past decade, has significantly improved and developed according to the advancements in the science and patient's demands and needs. Conventional options in prosthodontics for substituting a missing single tooth include the removable partial denture, partial and full coverage bridgework, and resin-bonded bridgework. Dental implants have gained increasing popularity over the years as they are capable of restoring the function to near normal in both partial and completely edentulous arches. With substantial evidence available, fixed implant-supported prosthesis are fully acknowledged as a reliable treatment option for the replacement of single or multiple missing teeth nowadays. While dental implants are increasingly becoming the choice of replacement for missing teeth, the impediments associated with them are progressively emerging too.

Key words: Implant complications, implant failures, peri-implantitis

\section{INTRODUCTION}

Understanding the pattern of tooth loss in a population helps in determining the quality of dental health care being provided, which varies geographically and culturally between countries. Studies have demonstrated that dental caries and periodontal diseases are frequent reasons for tooth extraction. ${ }^{[1-4]}$ In Pakistan, advanced dental caries (63.1\%) followed by periodontitis $(26.2 \%)$ are two major reasons for tooth loss. ${ }^{[5]}$

Once a tooth is lost, an individual may seek its replacement so that his/her function and esthetics could be restored. Clinical prosthodontics, during the past decade, has significantly improved and developed according to the advancements in the science and patient's demands and needs. Conventional options in prosthodontics for substituting a missing single

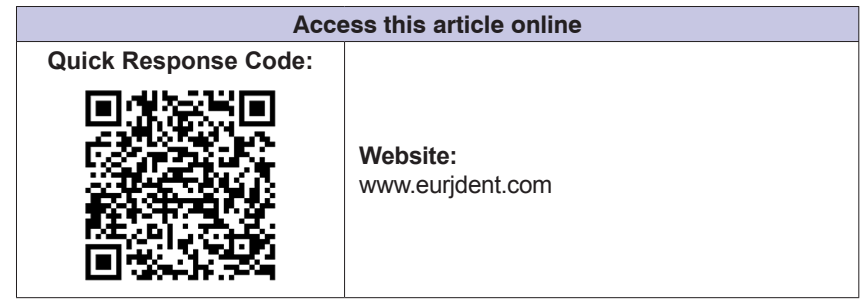

tooth include the removable partial denture, partial and full coverage bridgework, and resin-bonded bridgework. ${ }^{[6]}$

An attractive alternative to conventional dentures and bridges became available with the introduction of implants into dental industry. ${ }^{[6,7]}$ At present, both single crown implants and implant-supported fixed partial dentures (FPDs) are the available options. The basis for dental implants is osseointegration, where osteoblasts grow and directly integrate with the titanium surface of the implants surgically placed inside the alveolar bone. ${ }^{[7]}$ Dental implants have gained wide popularity over the years as they are capable of restoring the function to near normal in both partial and completely edentulous arches.

This is an open access article distributed under the terms of the Creative Commons Attribution-NonCommercial-ShareAlike 3.0 License, which allows others to remix, tweak, and build upon the work non-commercially, as long as the author is credited and the new creations are licensed under the identical terms.

For reprints contact: reprints@medknow.com

How to cite this article: Hanif A, Qureshi S, Sheikh Z, Rashid H. Complications in implant dentistry. Eur J Dent 2017;11:135-40.

DOI: 10.4103/ejd.ejd_340_16 
Numerous systematic reviews have been conducted on the survival and complication rates of FPDs supported by implants. Good survival rates of up to 10 years have been reported for both single-unit ${ }^{[8,9]}$ and multiple-unit ${ }^{[10-12]}$ implant-supported FPDs. With substantial evidence available, fixed implant-supported prostheses are fully acknowledged as a reliable treatment option for the replacement of single or multiple missing teeth nowadays. However, the survival rates generally refer to the prosthesis that continued its clinical service during definite follow-up period and this does not necessarily render them free of complications.

While dental implants are increasingly becoming the choice of replacement for missing teeth, the impediments associated with them are progressively emerging too. The aim of the current review is to discuss specific complications associated with dental implants. Management protocols and possible means of avoiding certain complications are also briefly discussed.

\section{COMPLICATIONS ASSOCIATED WITH DENTAL IMPLANTS}

Implant-supported single crowns and multiple implant-supported bridges may suffer from various mechanical, biological, or technical complications [Table 1]..$^{[12,13]}$ Poor patient selection is one of the important factors that adversely contribute toward failures in implant dentistry. ${ }^{[14]}$

\section{Mechanical complications}

Mechanical complications are usually a sequel to biomechanical overloading. ${ }^{[15,16]}$ Factors contributing to the biomechanical overloading are poor implant position/angulation [Figure 1] (cuspal inclination, implant inclination, horizontal offset of the implant, and apical offset of the implant), ${ }^{[17,18]}$ insufficient posterior support (i.e., missing posterior teeth), and inadequate available bone or the presence of excessive forces due to the parafunctional habits, that is, bruxism. ${ }^{[18-20]}$

\section{Screw loosening}

Overloading of the implants usually causes loosening or fracture of the implant component. ${ }^{[21]}$ Goodacre et al. ${ }^{[22]}$ stated that screw loosening or fracture prevailed more with the prosthetic screws as opposed to the abutment screws. Implants restored with single crowns have shown more screw loosening as compared to multiple implants with multiple

\begin{tabular}{lll}
$\begin{array}{l}\text { Table 1: Complications associated with dental } \\
\text { implants }\end{array}{ }^{[2,13]}$ & \\
\hline $\begin{array}{l}\text { Mechanical } \\
\text { complications }\end{array}$ & $\begin{array}{l}\text { Technical } \\
\text { complications }\end{array}$ & $\begin{array}{l}\text { Biologic } \\
\text { complications }\end{array}$ \\
\hline $\begin{array}{l}\text { Screw } \\
\text { loosening }\end{array}$ & $\begin{array}{l}\text { Fracture of veneering } \\
\text { porcelain }\end{array}$ & $\begin{array}{l}\text { Adverse soft-tissue } \\
\text { reactions }\end{array}$ \\
Screw fracture & $\begin{array}{l}\text { Fracture of the framework } \\
\text { in implant-supported }\end{array}$ & $\begin{array}{l}\text { Sensory } \\
\text { disturbances }\end{array}$ \\
& fixed partial dentures & $\begin{array}{l}\text { Progressive } \\
\text { marginal bone } \\
\text { Cement failure }\end{array}$ \\
& & $\begin{array}{l}\text { loss, loss of } \\
\text { integration }\end{array}$ \\
& & \\
& &
\end{tabular}

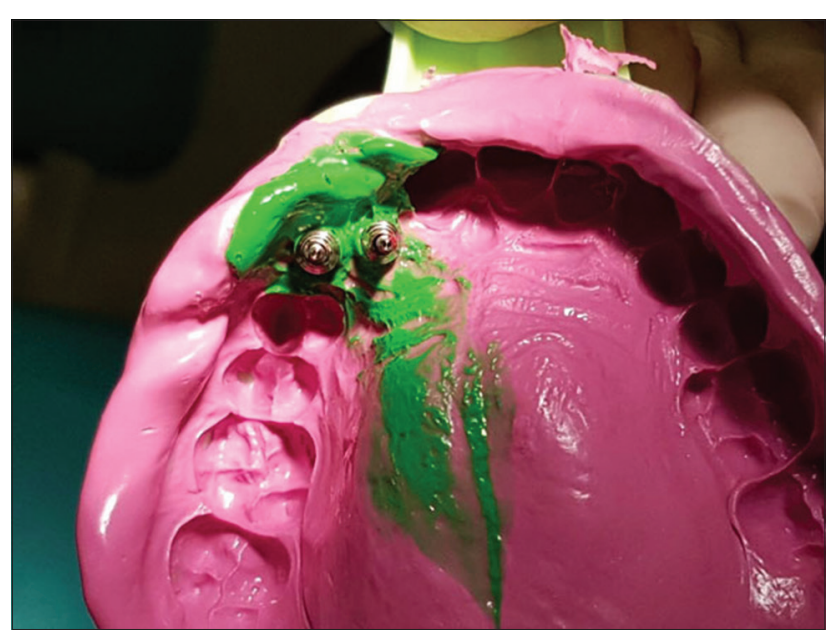

Figure 1: An open tray impression taken using addition cured silicone. Poor implant angulation can be judged which could lead to a mechanical failure

restored units, ${ }^{[23]}$ and mandibular molar implant restorations are more affected by screw loosening as compared to the maxillary ones. In another study, the incidences of loosening of the abutment screw or the abutment were found to be $59.6 \%$ in a follow-up of 15 years. ${ }^{[24]}$ In a systemic review by Pjetursson et al., ${ }^{[25]}$ the yearly rate of abutment or screw loosening ranged from $0.62 \%$ to $2.29 \%$ that converts into a 5 -year complication rate ranging from $3.1 \%$ to $10.8 \%$. In another follow-up study of Branemark single-tooth implants, screw loosening was reported to be the most frequent complication. ${ }^{[26]}$

To ease the incidence of screw loosening, it is advised to maximize the joint clamping forces while curtailing joint separating forces. ${ }^{[27]}$ Joint separating forces include excursive contacts, cantilevered contacts, interproximal contacts, off-axis centric contacts, and nonpassive frameworks. In an article by SadidZadeh et al. ${ }^{[28]}$, it was suggested to torque the abutment or the screw retained crown, with twice the force recommended by the manufacturer at an interval of 5 
min between each rotation. Over the course of years, many manufacturers have revised the conventional implant components to reduce the incidents of screw loosening. ${ }^{[29,30]}$

\section{Screw/implant fracture}

There are two major causes of implant fracture: biomechanical overloading and peri-implant vertical bone loss. ${ }^{[31]}$ The risk of implant fracture increases multifold when the vertical bone loss is severe enough to concur with the apical limit of the screw. ${ }^{[32-34]}$ Implant fractures are also attributable to flaws in the designs and manufacturing of implant itself. ${ }^{[3,36]}$ Unnoticed and recurrent screw loosening is a risk factor for dental implant fracture, which indicates change in the prosthesis design. ${ }^{[3]}$

The most frequently encountered fracture is of the hexagonal head away from the main body of the screw. ${ }^{[38]}$ When a screw is loose, it is more disposed to excessive sideward load. Fracture of the implant abutment screw can be a grim setback as the remaining fragment inside the implant jeopardizes the efficient functioning of the implant. ${ }^{[39,40]}$ When patients wear an implant-supported prosthesis (fixed or removable), there is a decrease in the occlusal forces which ranges from 200 to $300 \mathrm{~N} .{ }^{[41]}$ The failure of implant abutments occurs when the lateral forces exceed $370 \mathrm{~N}$ for the abutments having the joint depth of at least $2.1 \mathrm{~mm}$ and $530 \mathrm{~N}$ with a joint depth of at least $5.5 \mathrm{~mm} \cdot{ }^{[42-44]}$

Implants with a smaller diameter of 4 and $3.75 \mathrm{~mm}$ are inclined to fractures more easily than those with the greater diameter. ${ }^{[35,36,45]}$ It has been reported that an implant having a diameter of $5 \mathrm{~mm}$ is three times stronger than the one with the diameter of $3.75 \mathrm{~mm}$, while an implant of $6 \mathrm{~mm}$ diameter is 6 times stronger than a $3.75 \mathrm{~mm}$ implant. ${ }^{[4]}$ The risk factors associated with implant components are categorized into three groups and are enumerated in Table $2 .{ }^{[37,39]}$ Abutment screw fracture and loosening can be reduced if certain strategies are followed. These include careful treatment planning, understanding of the occlusal scheme, tightening the implant to the recommended torque, and routine follow-up appointments. ${ }^{[4]}$

\begin{tabular}{|c|c|c|}
\hline Periodontal factors & Implant factors & $\begin{array}{l}\text { Prosthetic } \\
\text { factors }\end{array}$ \\
\hline Pocket depth >5 mm & Diameter <4 mm & Loosening/torsion \\
\hline Bone loss & Crown/implant $>1$ & Prosthesis screw \\
\hline Occlusal overload (bruxism) & Implants design & $\begin{array}{l}\text { Cantilevers } \\
\text { Ceramic fracture }\end{array}$ \\
\hline
\end{tabular}

\section{Cement failure}

Cement failure is another consequence of biomechanical overload, typically affects the prosthesis attachment and may be treated by recementation procedure. ${ }^{[21]}$ With the advancements in material science, particularly for luting agents, the incidence of decementation has reduced significantly. ${ }^{[28]}$ However, careful treatment planning and clinical criteria must be followed to avoid such incidences.

\section{Technical complications}

The frequency of occurrences of technical complications is greater in implant-supported FPDs as compared to the implant-supported removable prosthesis. ${ }^{[48]}$

\section{Fracture of the framework}

Whenever there is a rigid connection between the osseointegrated implant and the fixed subsequent framework, the strains are inevitably induced in every component of the framework. ${ }^{[49]}$ The additional functional load produces supplementary strains, which affect the bone-implant-prosthesis assembly. ${ }^{[50,51]}$ Hence, the challenge remains for a prosthodontist to deliver a tolerable prosthesis that does not jeopardize the endurance of the treatment. ${ }^{[52,53]}$ Therefore, passive fit of the framework has been advocated as a requirement for successful long-term osseointegration of the implant with the surrounding bone. ${ }^{[54-56]}$

The problem of fracture of framework is reportedly exaggerated in partially edentulous jaws, because the implant-abutment interface and abutment retention screw are exposed to higher lateral bending loads, tipping, and elongation as compared to bilaterally splinted implants in a completely edentulous jaw. ${ }^{[57-59]}$ The length of the cast bar or framework span is directly proportional to the construction-related distortion, ${ }^{[60]}$ which could get worsened by nonparallel placement of dental implants.

To correct the gross misfit of the abutment-superstructure relationship, cutting the framework or bar and then joining the sections by welding or soldering is recommended, but both techniques may further impair the original fit. ${ }^{[61]}$ Since the corrective methods usually lead to a misfit, in order to avoid the need for such corrections, it is recommended that effort must be made to improve the original/initial fit of the cast frameworks. ${ }^{[62]}$ Factors that influence the accuracy of the initial fit of the framework include the impression material, ${ }^{[63,64]}$ impression technique, ${ }^{[62-64]}$ and positional stability ${ }^{[64,65]}$ of the transfer posts. Refined approaches and 
detailed and accurate prosthodontic procedures are still a requisite to achieve a passive fit with an implant-supported superstructure. ${ }^{[66]}$

\section{Fracture of veneering porcelain}

Metal-ceramic restorations are the most common types of restorations in clinical dentistry ${ }^{[67,68]}$ With the passage of time, esthetic demands of the patients have risen and thus driven the clinicians to focus on all-ceramic restorations. ${ }^{[69]}$ Zirconia restorations are promising, and the material is even being used to fabricate implant abutments for cement-retained restorations or for direct veneering for screw-retained prosthesis. ${ }^{[69]}$

Fracture of the veneering ceramic is another common complication associated with single-implant restorations. ${ }^{[28,70,71]}$ Sadid-Zadeh et al. ${ }^{[28]}$ concluded that of a total of 5052 ceramic and porcelain fused to metal restorations, 172 failed due to chipping off, which makes it $3.4 \%$ of the complications associated, at a mean follow-up of 5 years. The incidence of the fracture of the veneering ceramic can be reduced by following the clinical recommendations, that is, by reducing the occlusal table, preventing heavy occlusal contacts, keeping shallow cuspal heights, and by providing adequate thickness of the overlying ceramic.

\section{Peri-implantitis}

Biological failures include bacterial infections, microbial plaque buildup, progressive bone loss, and sensory disruptions. ${ }^{[72-74]}$ Biological complications are subcategorized into early biological failures and late implant failures, where the early failures are attributed to the failure of placing the surgical implant under proper aseptic measures ${ }^{[74-76]}$ and the late complications are typically peri-implantitis and infections bred by bacterial plaque. ${ }^{[77,78]}$

Peri-implant disease is defined as the inflammatory pathological change that takes place in the soft and hard tissues surrounding an osseointegrated implant [Figures 2 and 3]. ${ }^{[79]}$ When an implant is successfully osseointegrated, the peri-implant disease that occurs is the consequence of disparity between the host defense and increasing bacterial load. ${ }^{80]}$ It usually takes about 5 years for the peri-implant disease to progress and exhibit clinical signs and symptoms. ${ }^{[73,74,81]}$ The incidence of peri-implantitis and implant loss could be greater if the studies with longer follow-up periods are evaluated. ${ }^{[82]}$

In a healthy environment around the implant, the tissues play a pivotal role in preventing the spread of agents that can be pathognomonic, and if the biological barrier is breached, it could lead to bacterial contamination around the bone resulting in hasty destruction of the tissues surrounding the implant. ${ }^{[83]}$ The peri-implant disease is also related to unequal occlusal load distribution, which may lead to loosening of the superstructure, infection of the surrounding area, eventually culminating into the inflammatory process. ${ }^{[84]}$ Predisposing systemic conditions include uncontrolled diabetes mellitus, osteoporosis, smoking, long-standing treatment with steroids, uncontrolled periodontitis, radiation therapy, and chemotherapeutics. ${ }^{[80,85,86]}$ Table 3 enumerates clinical and radiographic symptoms that may be associated with peri-implant disease.

The peri-implant disease treatment strategies have been explored and employed to prevent failure of the implant treatment. ${ }^{[82]}$ They include nonsurgical mechanical debridement, local antimicrobial delivery in periodontitis and peri-implantitis, and surgical debridement with bone grafting. Implant removal is warranted if there is more than $60 \%$ of bone loss following peri-implantitis, and there is an evidence of mobility. ${ }^{[87]}$

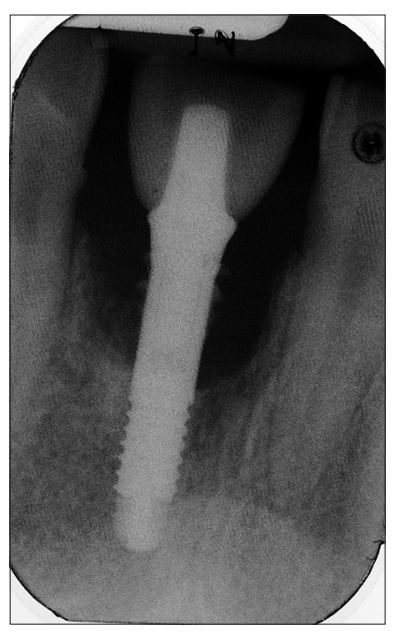

Figure 2: Radiographic picture showing significant bone loss around the implant

\begin{tabular}{l} 
Table 3: Clinical and radiographic symptoms of \\
peri-implantitis ${ }^{[6,87]}$ \\
\hline Probing depth $<6 \mathrm{~mm}$ \\
Bleeding on probing/suppuration \\
Attachment loss/bone loss of $2.5 \mathrm{~mm}$ \\
Vertical destruction of crestal bone on radiographs \\
Possible swelling and hyperplasia of the peri-implant tissues \\
Pain (unusual) if present, depicts acute infection
\end{tabular}




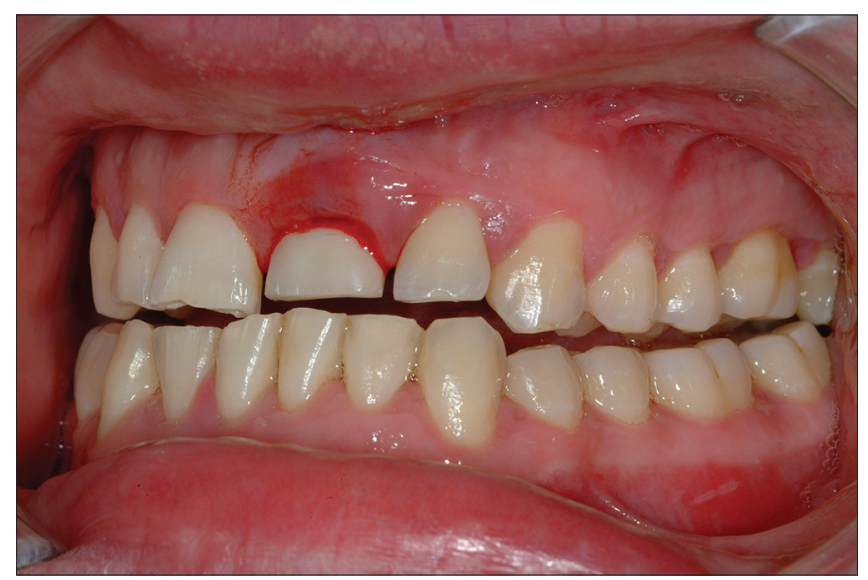

Figure 3: Soft-tissue inflammation caused due to peri-implantitis

\section{Financial support and sponsorship}

Nil.

\section{Conflicts of interest}

There are no conflicts of interest.

\section{REFERENCES}

1. Murray H, Locker D, Kay EJ. Patterns of and reasons for tooth extractions in general dental practice in Ontario, Canada. Community Dent Oral Epidemiol 1996;24:196-200.

2. Reich E, Hiller KA. Reasons for tooth extraction in the Western states of Germany. Community Dent Oral Epidemiol 1993;21:379-83.

3. Ong G, Yeo JF, Bhole S. A survey of reasons for extraction of permanent teeth in Singapore. Community Dent Oral Epidemiol 1996;24:124-7.

4. Angelillo IF, Nobile CG, Pavia M. Survey of reasons for extraction of permanent teeth in Italy. Community Dent Oral Epidemiol 1996;24:336-40.

5. Haseeb M, Ali K, Munir MF. Causes of tooth extraction at a tertiary care centre in Pakistan. J Pak Med Assoc 2012;62:812-5.

6. Chan R, Tseng T. Single tooth replacement-expanded treatment options. Aust Dent J 1994;39:137-49.

7. Zarb G, Albrektsson T, editors. Introduction to osseointegration. In: Branemark PI, editor. Tissue-Integrated Prosthesis: Osseointegration in Clinical Dentistry. Chicago, Berlin: Quintessence; 1985.

8. Jung RE, Pjetursson BE, Glauser R, Zembic A, Zwahlen M, Lang NP. A systematic review of the 5-year survival and complication rates of implant-supported single crowns. Clin Oral Implants Res 2008;19:119-30.

9. Jung RE, Zembic A, Pjetursson BE, Zwahlen M, Thoma DS. Systematic review of the survival rate and the incidence of biological, technical, and aesthetic complications of single crowns on implants reported in longitudinal studies with a mean follow-up of 5 years. Clin Oral Implants Res 2012;23 Suppl 6:2-21.

10. Pjetursson BE, Tan K, Lang NP, Brägger U, Egger M, Zwahlen M. A systematic review of the survival and complication rates of fixed partial dentures (FPDs) after an observation period of at least 5 years. Clin Oral Implants Res 2004;15:625-42.

11. Pjetursson BE, Brägger U, Lang NP, Zwahlen M. Comparison of survival and complication rates of tooth-supported fixed dental prostheses (FDPs) and implant-supported FDPs and single crowns (SCs). Clin Oral Implants Res 2007;18 Suppl 3:97-113.

12. Henry PJ, Laney WR, Jemt T, Harris D, Krogh PH, Polizzi G, et al. Osseointegrated implants for single-tooth replacement: A prospective 5-year multicenter study. Int J Oral Maxillofac Implants 1996;11:450-5.

13. Taylor RC, McGlumphy EA, Tatakis DN, Beck FM. Radiographic and clinical evaluation of single-tooth Biolok implants: A 5-year study. Int J Oral Maxillofac Implants 2004;19:849-54.

14. Pjetursson BE, Thoma D, Jung R, Zwahlen M, Zembic A. A systematic review of the survival and complication rates of implant-supported fixed dental prostheses (FDPs) after a mean observation period of at least 5 years. Clin Oral Implants Res 2012;23 Suppl 6:22-38.

15. Gammage DD, Bowman AE, Meffert RM. Clinical management of failing dental implants: Four case reports. J Oral Implantol 1989;15:124-31.

16. Tolman DE, Laney WR. Tissue-integrated prosthesis complications. Int J Oral Maxillofac Implants 1992;7:477-84.

17. Weinberg LA, Kruger B. A comparison of implant/prosthesis loading with four clinical variables. Int J Prosthodont 1995;8:421-33.

18. Abrahams JJ. Dental CT imaging: A look at the jaw. Radiology 2001;219:334-45.

19. Rieger MR, Mayberry M, Brose MO. Finite element analysis of six endosseous implants. J Prosthet Dent 1990;63:671-6.

20. Katona TR, Goodacre CJ, Brown DT, Roberts WE. Force-moment systems on single maxillary anterior implants: Effects of incisal guidance, fixture orientation, and loss of bone support. Int J Oral Maxillofac Implants 1993;8:512-22.

21. Liaw K, Delfini RH, Abrahams JJ. Dental Implant Complications. Semin Ultrasound CT MR 2015;36:427-33.

22. Goodacre CJ, Bernal G, Rungcharassaeng K, Kan JY. Clinical complications with implants and implant prostheses. J Prosthet Dent 2003;90:121-32.

23. Balshi TJ, Hernandez RE, Pryszlak MC, Rangert B. A comparative study of one implant versus two replacing a single molar. Int J Oral Maxillofac Implants 1996;11:372-8.

24. Jemt T. Single implants in the anterior maxilla after 15 years of follow-up: Comparison with central implants in the edentulous maxilla. Int J Prosthodont 2008;21:400-8.

25. Pjetursson BE, Asgeirsson AG, Zwahlen M, Sailer I. Improvements in implant dentistry over the last decade: Comparison of survival and complication rates in older and newer publications. Int J Oral MaxIllOfac IMplants 2014;29(suppl):308-24.

26. Haas R, Mensdorff-Pouilly N, Mailath G, Watzek G. Brånemark single tooth implants: A preliminary report of 76 implants. J Prosthet Dent 1995;73:274-9.

27. McGlumphy EA, Mendel DA, Holloway JA. Implant screw mechanics. Dent Clin North Am 1998;42:71-89.

28. Sadid-Zadeh R, Kutkut A, Kim H. Prosthetic failure in implant dentistry. Dent Clin North Am 2015;59:195-214.

29. Malathi G, Chandra R. Mechanical complications with implants. IJDA 2011;3:555-8.

30. Schwarz MS. Mechanical complications of dental implants. Clin Oral Implants Res 2000;11 Suppl 1:156-8.

31. Gupta S, Gupta H, Tandan A. Technical complications of implant-causes and management: A comprehensive review. Natl J Maxillofac Surg 2015;6:3-8.

32. Piattelli A, Scarano A, Piattelli M, Vaia E, Matarasso S. Hollow implants retrieved for fracture: A light and scanning electron microscope analysis of 4 cases. J Periodontol 1998;69:185-9.

33. Rangert B, Krogh PH, Langer B, Van Roekel N. Bending overload and implant fracture: A retrospective clinical analysis. Int J Oral Maxillofac Implants 1995;10:326-34.

34. Goodacre CJ, Kan JY, Rungcharassaeng K. Clinical complications of osseointegrated implants. J Prosthet Dent 1999;81:537-52.

35. Balshi TJ. An analysis and management of fractured implants: A clinical report. Int J Oral Maxillofac Implants 1996;11:660-6.

36. Eckert SE, Meraw SJ, Cal E, Ow RK. Analysis of incidence and associated factors with fractured implants: A retrospective study. Int J Oral Maxillofac Implants 2000;15:662-7.

37. Sánchez-Pérez A, Moya-Villaescusa MJ, Jornet-Garcia A, Gomez S Etiology, risk factors and management of implant fractures. Med Oral Patol Oral Cir Bucal 2010;15:e504-8.

38. Zarb GA, Schmitt A. The longitudinal clinical effectiveness of osseointegrated dental implants: The Toronto study. Part III: Problems and complications encountered. J Prosthet Dent 1990;64:185-94.

39. Walia MS, Arora S, Luthra R, Walia PK. Removal of fractured dental implant screw using a new technique: A case report. J Oral Implantol 2012;38:747-50

40. Kreissl ME, Gerds T, Muche R, Heydecke G, Strub JR. Technical complications of implant-supported fixed partial dentures in partially edentulous cases after an average observation period of 5 years. Clin Oral Implants Res 2007;18:720-6.

41. Tagger Green N, Machtei EE, Horwitz J, Peled M. Fracture of dental 
implants: Literature review and report of a case. Implant Dent 2002;11:137-43.

42. Brunski JB, Puleo DA, Nanci A. Biomaterials and biomechanics of oral and maxillofacial implants: Current status and future developments. Int J Oral Maxillofac Implants 2000;15:15-46.

43. Mericske-Stern R, Assal P, Mericske E, Bürgin W. Occlusal force and oral tactile sensibility measured in partially edentulous patients with ITI implants. Int J Oral Maxillofac Implants 1995;10:345-53.

44. Möllersten L, Lockowandt P, Lindén LA. Comparison of strength and failure mode of seven implant systems: An in vitro test. J Prosthet Dent 1997;78:582-91.

45. Kwon K, Sim K, Cha J, Kim E, Lee J. Clinical and scanning electron microscopic analysis of fractured dental implants: A retrospective clinical analysis. J Korean Assoc Oral Maxillofac Surg 2012;38:371-8.

46. Proceedings of the $4^{\text {th }}$ international symposium on implant dentistry: Focus on esthetics. San Diego, California, January 27-29, 1994. Abstracts. J Prosthet Dent 1994;72:623-34.

47. Brägger U, Aeschlimann S, Bürgin W, Hämmerle CH, Lang NP. Biological and technical complications and failures with fixed partial dentures (FPD) on implants and teeth after four to five years of function. Clin Oral Implants Res 2001;12:26-34.

48. Jemt T. Failures and complications in 391 consecutively inserted fixed prostheses supported by Brånemark implants in edentulous jaws: A study of treatment from the time of prosthesis placement to the first annual checkup. Int J Oral Maxillofac Implants 1991;6:270-6.

49. Sahin S, Cehreli MC. The significance of passive framework fit in implant prosthodontics: Current status. Implant Dent 2001;10:85-92.

50. Kan JY, Rungcharassaeng K, Bohsali K, Goodacre CJ, Lang BR. Clinical methods for evaluating implant framework fit. J Prosthet Dent 1999;81:7-13.

51. Wee AG, Aquilino SA, Schneider RL. Strategies to achieve fit in implant prosthodontics: A review of the literature. Int J Prosthodont 1999;12:167-78.

52. Fusayama T, Wakumoto S, Hosada H. Accuracy of fixed partial dentures made by various soldering techniques and onepiece castings. J Prosthet Dent 1964;14:334-42.

53. Kallus T, Bessing C. Loose gold screws frequently occur in full-arch fixed prostheses supported by osseointegrated implants after 5 years. Int J Oral Maxillofac Implants 1994;9:169-78.

54. Nicholls JI. The measurement of distortion: Theoretical considerations. J Prosthet Dent 1977;37:578-86.

55. Nicholls JI. The measurement of distortion: Mathematical considerations. J Prosthet Dent 1978;39:339-43.

56. Nicholls JL. The measurement of distortion: Concluding remarks. J Prosthet Dent 1980;43:218-23.

57. Yanase RT, Binon PP, Jemt T, Gulbransen HJ, Parel S. Current issue forum. How do you test a cast framework for a full arch fixed implant supported prosthesis? Int J Oral Maxillofac Implants 1994;9:471-4.

58. Binon PP. The spline implant: Design, engineering, and evaluation. Int J Prosthodont 1996;9:419-33.

59. Riedy SJ, Lang BR, Lang BE. Fit of implant frameworks fabricated by different techniques. J Prosthet Dent 1997;78:596-604.

60. Zoidis PC, Winkler S, Karellos ND. The effect of soldering, electrowelding, and cast-to procedures on the accuracy of fit of cast implant bars. Implant Dent 1996;5:163-8.

61. Thoupos GA, Zouras CS, Winkler S, Roussos VG. Connecting implant framework segments. Implant Dent 1995;4:97-9.

62. Phillips KM, Nicholls JI, Ma T, Rubinstein J. The accuracy of three implant impression techniques: A three-dimensional analysis. Int J Oral Maxillofac Implants 1994;9:533-40.

63. Spector MR, Donovan TE, Nicholls JI. An evaluation of impression techniques for osseointegrated implants. J Prosthet Dent 1990;63:444-7.

64. Assif D, Fenton A, Zarb G, Schmitt A. Comparative accuracy of implant impression procedures. Int J Periodontics Restorative Dent
1992;12:112-21.

65. Humphries RM, Yaman P, Bloem TJ. The accuracy of implant master casts constructed from transfer impressions. Int J Oral Maxillofac Implants 1990;5:331-6.

66. Romero GG, Engelmeier R, Powers JM, Canterbury AA. Accuracy of three corrective techniques for implant bar fabrication. J Prosthet Dent 2000;84:602-7.

67. Hebel KS, Gajjar RC. Cement-retained versus screw-retained implant restorations: Achieving optimal occlusion and esthetics in implant dentistry. J Prosthet Dent 1997;77:28-35.

68. Segal BS. Retrospective assessment of 546 all-ceramic anterior and posterior crowns in a general practice. J Prosthet Dent 2001;85:544-50.

69. Ekfeldt A, Fürst B, Carlsson GE. Zirconia abutments for single-tooth implant restorations: A retrospective and clinical follow-up study. Clin Oral Implants Res 2011;22:1308-14.

70. Sailer I, Mühlemann S, Zwahlen M, Hämmerle CH, Schneider D. Cemented and screw-retained implant reconstructions: A systematic review of the survival and complication rates. Clin Oral Implants Res 2012;23 Suppl 6:163-201.

71. Vigolo P, Mutinelli S, Givani A, Stellini E. Cemented versus screw-retained implant-supported single-tooth crowns: A 10-year randomised controlled trial. Eur J Oral Implantol 2012;5:355-64.

72. Berglundh T, Persson L, Klinge B. A systematic review of the incidence of biological and technical complications in implant dentistry reported in prospective longitudinal studies of at least 5 years. J Clin Periodontol 2002;29 Suppl 3:197-212.

73. Klinge B, Hultin M, Berglundh T. Peri-implantitis. Dent Clin North Am 2005;49:661-76, vii-viii.

74. Quirynen M, De Soete M, van Steenberghe D. Infectious risks for oral implants: A review of the literature. Clin Oral Implants Res 2002;13:1-19.

75. Snauwaert K, Duyck J, van Steenberghe D, Quirynen M, Naert I. Time dependent failure rate and marginal bone loss of implant supported prostheses: A 15-year follow-up study. Clin Oral Investig 2000;4:13-20.

76. Esposito M, Hirsch JM, Lekholm U, Thomsen P. Biological factors contributing to failures of osseointegrated oral implants. (II) Etiopathogenesis. Eur J Oral Sci 1998;106:721-64.

77. Quirynen M, Teughels W. Microbiologically compromised patients and impact on oral implants. Periodontol 2000 2003;33:119-28.

78. Tonetti MS. Risk factors for osseodisintegration. Periodontol 2000 1998;17:55-62.

79. Mombelli A, Lang NP. The diagnosis and treatment of peri-implantitis. Periodontol 2000 1998;17:63-76.

80. Heitz-Mayfield LJ. Peri-implant diseases: Diagnosis and risk indicators. J Clin Periodontol 2008;35 8 Suppl: 292-304.

81. Mombelli A, Müller N, Cionca N. The epidemiology of peri-implantitis. Clin Oral Implants Res 2012;23 Suppl 6:67-76.

82. Rashid H, Sheikh Z, Vohra F, Hanif A, Glogauer M. Peri-implantitis: A re-view of the disease and report of a case treated with allograft to achieve bone regeneration. Dent Open J 2015;2:87-97.

83. Lang NP, Wilson TG, Corbet EF. Biological complications with dental implants: Their prevention, diagnosis and treatment. Clin Oral Implants Res 2000;11 Suppl 1:146-55.

84. Georgiev T. Kamen Nogalchev Local complications occurring during dental implantation. J IMAB: Annual Proceeding (Scientific Papers). 2010;16:35-7

85. Prathapachandran J, Suresh N. Management of peri-implantitis. Dent Res J (Isfahan) 2012;9:516-21.

86. Albrektsson T, Isidor F. Consensus report: Implant therapy. In: Lang NP, Karring T, editors. Proceedings of the $1^{\text {st }}$ European Workshop on Periodontology. Berlin: Quintessence; 1994. p. 365-9.

87. Lang NP, Lindhe J. Clinical Periodontology and Implant Dentistry. Blackwell Munksgaard: Copenhagen, Denmark: John Wiley and Sons; 2015. 